\title{
Hypolipidemic Effects of Sophora flavescens and Its Constituents in Poloxamer 407-Induced Hyperlipidemic and Cholesterol-Fed Rats
}

\author{
Hyun Young KIm, ${ }^{a}$ Da Mi Jeong, ${ }^{b}$ Hee Jin Jung, ${ }^{b}$ Yu Jung Jung, ${ }^{b}$ Takako Yokozawa, ${ }^{c}$ and \\ Jae Sue CHOI ${ }^{*}, b$ \\ ${ }^{a}$ College of Pharmacy, Seoul National University; San 56-1, Shillim-Dong, Kwanak-gu, Seoul 151-742, Korea: ${ }^{b}$ Faculty \\ of Food Science and Biotechnology, Pukyong National University; Busan 608-737, Korea: and ${ }^{c}$ Institute of Natural \\ Medicine, University of Toyama; 2630 Sugitani, Toyama 930-0194, Japan. \\ Received May 14, 2007; accepted October 1, 2007; published online November 5, 2007
}

In this study, we investigated the hypolipidemic effects of Sophora flavescens in poloxamer 407-induced hyperlipidemic and cholesterol-fed rats. The $\mathrm{MeOH}$ extract and 4 fractions of $S$. flavescens were administered at doses of 250 and $100 \mathrm{mg} / \mathrm{kg}$ body weight, respectively, once a day for $3 \mathrm{~d}$ to the poloxamer 407 -induced hyperlipidemic rats. Serum lipid levels such as total cholesterol (TC), triglycerides (TG), and low-density lipoprotein-cholesterol (LDL-C) were markedly elevated in the poloxamer 407-induced hyperlipidemic control rats, while lipid levels were significantly decreased in the rats administered the $\mathrm{MeOH}$ extract or 4 fractions of $S$. flavescens. In addition, serum high-density lipoprotein-cholesterol (HDL-C) was reduced in the poloxamer 407-induced hyperlipidemic control rats. However, oral administration of both the MeOH extract and 4 fractions significantly increased HDL-C levels. Of the tested fractions, the EtOAc fraction showed the strongest lipid-lowering effect, as well as a high antiatherogenic potential with atherogenic index (A.I.) values of less than 1.92. We also investigated the hypolipidemic effects of the main compounds of the EtOAc fraction, kurarinol and kuraridinol, using the hyperlipidemic and hypercholesterolemic animal models. Here, elevated TC, TG, and LDL-C levels in the poloxamer 407-induced hyperlipidemic and cholesterol-fed rats were significantly reduced after oral administration of the compounds, and HDL-C levels had a significant increase. Furthermore, A.I. values were lowered by administering kurarinol and kuraridinol. In particular, kuraridinol exhibited stronger protective activities against hyperlipidemia than kurarinol. These results suggest that $\boldsymbol{S}$. flavescens and its constituents may be effective cholesterol-lowering agents and useful for preventing hypercholesterolemic atherosclerosis.

Key words hyperlipidemic; hypercholesterolemic; Sophora flavescens; poloxamer 407; rat

Atherosclerosis is the major cause of heart disease, stroke, and death in both developed and developing countries. ${ }^{1)}$ It is well established that elevated blood lipid levels constitute the primary risk factor for atherosclerosis. ${ }^{2)}$ Many studies have shown that increased cholesterol concentrations in plasma cause coronary atherosclerosis. ${ }^{3-6)}$ In addition, hypercholesterolemia is shown to be one of the major risk factors of atherosclerosis by increasing plasma low-density lipoprotein (LDL) levels. ${ }^{7)}$ Recently, there has been much focus on the search for new drugs capable of reducing and/or regulating serum cholesterol and triglyceride levels, which has resulted in numerous reports on the significant activities of natural agents. ${ }^{8,9)}$ In particular, dietary plants with cholesterol-lowering activity are considered useful in preventing disorders such as atherosclerosis.

Sophora flavescens (Leguminosae) is a perennial shrub occurring wild, as well as cultivated, in northeast Asia. The dried root of $S$. flavescens is an important herbal medicine that is applied in folk medicine as an antipyretic, analgesic, anthelmintic, and a stomachic. ${ }^{10-13)}$ S. flavescens contains alkaloids, triterpenoids, and flavonoids ${ }^{11)}$ that have shown various biological activities such as the inhibition of phospholipase $\mathrm{C} \gamma 1$, melanogenesis, and cytotoxicity against human myeloid leukemia HL-60 cells. ${ }^{14-16)}$ In particular, a large number of flavonoids, including formononetin, kushenol $\mathrm{E}$, kushenol B, sophoraflavanone $\mathrm{G}$, kushenol L, kushenol M, kuraridin, kurarinone, kushenol $\mathrm{N}$, and kushenol $\mathrm{F}$, have been isolated and reported. ${ }^{10-13,16)}$ Among the flavonoids, kurarinone was reported to have potent cytotoxic activity against human MCF-7/6 breast cancer cells. ${ }^{17)}$ In addition, sophoraflavanone $\mathrm{G}$ and kurarinone exhibited protective effects against oxidative damage of the radical generator 2,2' azobis-(2-amidinopropane)-dihydrochloride (AAPH) in renal epithelial LLC-PK(1) cells. ${ }^{18)}$ Moreover, in a previous study, we demonstrated the antioxidative properties of flavonoids from $S$. flavescens as 1,1'-diphenyl-2-picrylhydrazyl (DPPH) radical and $\mathrm{ONOO}^{-}$scavengers in vitro. ${ }^{19)}$ However, the cholesterol-lowering effects of $S$. flavescens in hyperlipidemic and hypercholesterolemic animal models have not been studied.

In this study, we investigated the effects of $S$. flavescens and its constituents on serum lipid profiles, using poloxamer 407-induced hyperlipidemic rats and cholesterol-fed rats.

\section{MATERIALS AND METHODS}

General The ${ }^{1} \mathrm{H}$ - and ${ }^{13} \mathrm{C}$-NMR spectra were determined with a JEOL JNM ECP-400 spectrometer $\left(400 \mathrm{MHz}\right.$ for ${ }^{1} \mathrm{H}$ and $100 \mathrm{MHz}$ for ${ }^{13} \mathrm{C}$ ) in DMSO- $d_{6}$. The HMBC spectra were recorded using pulsed field gradients. Column chromatography was conducted using silica (Si) gel $60(70-230$ mesh, Merck, Germany), RP-18 Lichroprep (40-63 $\mu \mathrm{m}$, Merck, Germany), and Sephadex LH-20 (20-100 $\mu$, Sigma, St. Louis, MO, U.S.A.). TLC was conducted on precoated Merck Kieselgel $60 \mathrm{~F}_{254}$ plates $(20 \times 20 \mathrm{~cm}, 0.25 \mathrm{~mm})$ and RP-18 $\mathrm{F}_{254 \mathrm{~s}}$ plates $(5 \times 10 \mathrm{~cm}$, Merck, Germany) using $50 \%$ $\mathrm{H}_{2} \mathrm{SO}_{4}$ as a spray reagent. All solvents used in the column chromatography were of reagent grade and purchased from commercial sources.

Chemicals Poloxamer 407 (Pluronic F-127), olive oil, 
cholic acid, and cholesterol were purchased from Sigma (St. Louis, MO, U.S.A.). Total cholesterol (TC, Cholestezyme$\mathrm{V})$, triglyceride (TG, Triglyzyme-V), and high-density lipoprotein-cholesterol (HDL-C, HDL-C555) assay kits were purchased from Shinyang Chemical Co., Ltd. (Korea).

Plant Materials The S. flavescens Aiton (Leguminosae) roots were collected at Young Chun, Kyeong Buk, Korea in March 2004, and were authenticated by Prof. J. H. Lee at Kyung Hee University in Seoul, Korea. A voucher specimen (no. 20040320) was deposited in the author's laboratory (J. S. Choi).

Extraction, Fractionation, and Isolation The dried roots of $S$. flavescens $(10 \mathrm{~kg}$ ) were refluxed with $\mathrm{MeOH}$ for 3 $\mathrm{h}(3 \times 101)$. The total filtrate was then concentrated to dryness in vacuo at $40^{\circ} \mathrm{C}$ to render the $\mathrm{MeOH}$ extract $(2.2 \mathrm{~kg})$. This extract was suspended in $\mathrm{H}_{2} \mathrm{O}$ and then successively partitioned with $\mathrm{CH}_{2} \mathrm{Cl}_{2}$, EtOAc, and $n$-BuOH to yield $\mathrm{CH}_{2} \mathrm{Cl}_{2}$ $(230 \mathrm{~g})$, EtOAc $(250 \mathrm{~g})$, and $n-\mathrm{BuOH}(610 \mathrm{~g})$, as well as $\mathrm{H}_{2} \mathrm{O}$ $(1110 \mathrm{~g})$ residue. The EtOAc fraction $(250 \mathrm{~g})$ was first chromatographed over a silica ( $\mathrm{Si}$ ) gel column using $\mathrm{CH}_{2} \mathrm{Cl}_{2}-\mathrm{MeOH}$ under gradient conditions $\left(\mathrm{CH}_{2} \mathrm{Cl}_{2} \rightarrow\right.$ $\mathrm{CH}_{2} \mathrm{Cl}_{2}: \mathrm{MeOH}=20: 1 \rightarrow 1: 1, \mathrm{MeOH}$, gradient) to afford 21 fractions (Fr. 1-Fr. 21). Fraction 15 (32.28 g) was purified by $\mathrm{Si}$ gel with $\mathrm{CH}_{2} \mathrm{Cl}_{2}: \mathrm{MeOH}(20: 1 \rightarrow 1: 1, \mathrm{MeOH}$, gradient) to obtain 6 fractions (Fr. 15-1 to 15-6). Fraction 3 (Fr. $15-3,2.77 \mathrm{~g}$ ) was subjected to column chromatography over a $\mathrm{Si}$ gel column with $n$-hexane : EtOAc (1:1 to EtOAc), and yielded compound 1 (1.08 g). Fraction 4 (Fr. 15-4, $25 \mathrm{~g}$ ) was subjected to column chromatography on $\mathrm{Si}$ gel with $n$ hexane:EtOAc $(1: 2$ to EtOAc) to yield compound 2 $(3.20 \mathrm{~g})$. The chemical structures of compounds $\mathbf{1}$ and $\mathbf{2}$ were identified as kurarinol (1) and kuraridinol (2), respectively (Fig. 1).

Kurarinol (1) ${ }^{1} \mathrm{H}-\mathrm{NMR}\left(400 \mathrm{MHz}, \mathrm{DMSO}-d_{6}\right) \delta: 10.30$ (1H, s, OH-7), 9.54 (1H, s, OH-2'), $9.30\left(1 \mathrm{H}, \mathrm{s}, \mathrm{OH}-4^{\prime}\right), 7.21$ $\left(1 \mathrm{H}, \mathrm{d}, J=8.6 \mathrm{~Hz}, \mathrm{H}-6^{\prime}\right), 6.32\left(1 \mathrm{H}, \mathrm{d}, J=2.0 \mathrm{~Hz}, \mathrm{H}-3^{\prime}\right), 6.25$ $\left(1 \mathrm{H}, \mathrm{dd}, J=2.0,8.6 \mathrm{~Hz}, \mathrm{H}-5^{\prime}\right), 6.12(1 \mathrm{H}, \mathrm{s}, \mathrm{H}-6), 5.41(1 \mathrm{H}$, dd, $J=2.3,13.2 \mathrm{~Hz}, \mathrm{H}-2), 4.56$ (1H, br s, H-9"a), $4.48(1 \mathrm{H}$, brs, H-9"b), $3.70\left(3 \mathrm{H}, \mathrm{s}, \mathrm{OCH}_{3}\right), 2.80(1 \mathrm{H}, \mathrm{dd}, J=13.2$, $16.2 \mathrm{~Hz}, \mathrm{H}-3 \mathrm{ax}$ ), 2.50 (1H, dd, $J=2.3,16.2 \mathrm{~Hz}, \mathrm{H}-3 \mathrm{eq}), 2.48$ $\left(2 \mathrm{H}, \mathrm{m}, \mathrm{H}-1^{\prime \prime}\right), 2.31$ (1H, m, H-2"), $1.56\left(3 \mathrm{H}, \mathrm{s}, \mathrm{H}-10^{\prime \prime}\right), 1.22$ $\left(2 \mathrm{H}, \mathrm{m}, \mathrm{H}-3^{\prime \prime}\right), 1.00$ (2H, m, H-4"), and 0.95 (each 3H, s, H$\left.6^{\prime \prime}, 7^{\prime \prime}\right) .{ }^{13} \mathrm{C}-\mathrm{NMR}\left(100 \mathrm{MHz}, \mathrm{DMSO}-d_{6}\right) \delta$ : 189.18 (C-4), 162.70 (C-9), 162.53 (C-3'), 162.25 (C-7), 159.76 (C-5), $158.30\left(\mathrm{C}-4^{\prime}\right), 155.42\left(\mathrm{C}-2^{\prime}\right), 148.33\left(\mathrm{C}-8^{\prime \prime}\right), 127.48\left(\mathrm{C}-6^{\prime}\right)$, $116.58\left(\mathrm{C}-1^{\prime}\right), 111.02\left(\mathrm{C}-9^{\prime \prime}\right), 107.30(\mathrm{C}-8), 106.45\left(\mathrm{C}-5^{\prime}\right)$, 104.55 (C-10), 92.65 (C-6), 73.78 (C-2), 68.90 (C-5"), 55.45 $\left(\mathrm{OCH}_{3}\right), 46.85\left(\mathrm{C}-2^{\prime \prime}\right), 44.55(\mathrm{C}-3), 41.72\left(\mathrm{C}-4^{\prime \prime}\right), 29.64(\mathrm{C}-$ $\left.6^{\prime \prime}\right), 29.17\left(\mathrm{C}-7^{\prime \prime}\right), 27.61\left(\mathrm{C}-1^{\prime \prime}\right), 26.67\left(\mathrm{C}-3^{\prime \prime}\right)$, and $18.24(\mathrm{C}-$ $\left.10^{\prime \prime}\right)$.

Kuraridinol (2) ${ }^{1} \mathrm{H}-\mathrm{NMR} \quad\left(400 \mathrm{MHz}, \mathrm{DMSO}-d_{6}\right) \quad \delta$ : 14.86 (1H, s, OH-9), 10.17 (1H. s, OH-7), $7.94(1 \mathrm{H}, \mathrm{d}$, $J=15.6 \mathrm{~Hz}, \mathrm{H}-2), 7.86(1 \mathrm{H}, \mathrm{d}, J=15.6 \mathrm{~Hz}, \mathrm{H}-3), 7.43(1 \mathrm{H}, \mathrm{d}$, $\left.J=8.6 \mathrm{~Hz}, \mathrm{H}-6^{\prime}\right), 6.38\left(1 \mathrm{H}, \mathrm{d}, J=2.2 \mathrm{~Hz}, \mathrm{H}-3^{\prime}\right), 6.32(1 \mathrm{H}, \mathrm{dd}$, $\left.J=2.2,8.6 \mathrm{~Hz}, \mathrm{H}-5^{\prime}\right), 6.04(1 \mathrm{H}, \mathrm{s}, \mathrm{H}-6), 4.57(1 \mathrm{H}, \mathrm{brs}, \mathrm{H}-$ 9"a), 4.47 (1H, d, $\left.J=2.2 \mathrm{~Hz}, \mathrm{H}-9{ }^{\prime \prime} \mathrm{b}\right), 3.83\left(3 \mathrm{H}, \mathrm{s}, \mathrm{OCH}_{3}\right)$, 2.55 (2H, m, H-1"), 2.35 (1H, m, H-2"), 1.64 (3H, s, H-10"), 1.35 (2H, m, H-3"), 1.19 (2H, m, H-4"), 1.02 (3H, s, H-6"), and $1.01\left(3 \mathrm{H}, \mathrm{s}, \mathrm{H}-7^{\prime \prime}\right) .{ }^{13} \mathrm{C}-\mathrm{NMR}\left(100 \mathrm{MHz}, \mathrm{DMSO}-d_{6}\right) \delta$ : 191.96 (C-4), 165.28 (C-9), 162.75 (C-7), 161.14 (C-4'), 160.27 (C-5), 159.02 (C-2'), 148.00 (C-8"), 138.63 (C-2),



1

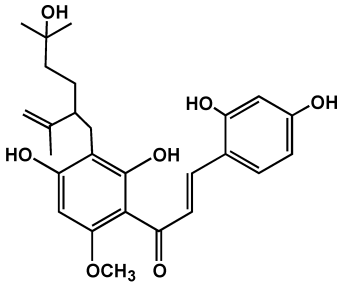

2
Fig. 1. The Chemical Structures of Kurarinol (1) and Kuraridinol (2)

$130.31\left(\mathrm{C}-6^{\prime}\right), 122.79$ (C-3), $113.74\left(\mathrm{C}-1^{\prime}\right), 110.92\left(\mathrm{C}-9^{\prime \prime}\right)$, 108.05 (C-5'), 106.73 (C-8), 104.41 (C-10), 102.58 (C-3'), $90.66(\mathrm{C}-6), 68.64\left(\mathrm{C}-5^{\prime \prime}\right), 55.49\left(\mathrm{OCH}_{3}\right), 46.41\left(\mathrm{C}-2^{\prime \prime}\right), 41.57$ $\left(\mathrm{C}-4^{\prime \prime}\right), 29.55$ (C-6"), 29.00 (C-7"), 27.10 (C-1"), 26.65 (C$\left.3^{\prime \prime}\right)$, and $17.85\left(\mathrm{C}-10^{\prime \prime}\right)$.

Animals and Treatments In these experiments we followed The Guidelines for Care and Use of Laboratory Animals as approved by Pukyong National University. Male Sprague-Dawley rats weighing $120-130 \mathrm{~g}$ were purchased from Samtako Inc. (Osan, Korea). The rats were housed in wire-bottomed cages in a controlled environment with approximate room temperature and relative humidity at $25^{\circ} \mathrm{C}$ and $60 \%$, respectively, and a 12-h light-dark cycle. The rats had free access to water and commercially prepared pellet chow (Samtako Inc., Osan, Korea) comprised of 24.0\% protein, $3.5 \%$ lipid, and $60.5 \%$ carbohydrate. With regard to changes in body weight, we found no statistically significant differences between the control and the sample-treated rats during the experimental period. Also, no cases of diarrheal symptoms were found.

Experimental Hyperlipidemic Diet The high-cholesterol diet was prepared by mixing the normal basal diet [composition (w/w): $48.3 \%$ carbohydrate, $23.5 \%$ crude protein, $5.9 \%$ crude fat, $5.9 \%$ crude ash, and $3.9 \%$ crude fiber (Sam \#31, Samtaco Bio Korea)] with cholic acid, cholesterol, and olive oil in a ratio of $950: 5: 20: 25$, and was then pelleted.

Poloxamer 407-Induced Hyperlipidemic Model Based on the method of Schmolka, ${ }^{20}$ we made all animals hyperlipidemic by an intraperitoneal injection (i.p.) of $400 \mathrm{mg} / \mathrm{kg}$ of Poloxamer 407, followed by a $6 \mathrm{~h}$ fast. The poloxamer 407 solution for i.p. was prepared by combining the agent with saline for injection, and then refrigerated overnight to facilitate dissolution of the Poloxamer 407 via the cold method. Two hours after administering the Poloxamer 407 the rats were treated with the prepared samples. Subsequent treatments were given once daily by oral gavage for $3 \mathrm{~d}$.

High-Cholesterol Diet Induced Hyperlipidemic Model In this model, the animals were fed a high-cholesterol diet for $7 \mathrm{~d}$. To identify the induction of hyperlipidemia, blood was collected from the tail vein using heparinized capillary tubes, and then assayed for the total cholesterol concentration using a standard enzymatic assay kit (Cholestezyme-V). The rats were then divided into 6 groups of 7 animals each by cholesterol level. Tested samples were provided orally once a day for a period of $3 \mathrm{~d}$.

Blood Sampling At the end of experimental period, and after $12 \mathrm{~h}$ of fasting, the rats were anesthetized with ethyl ether and killed by decapitation. Blood was collected from 
the neck wound and left at room temperature for $30 \mathrm{~min}$; the blood samples were then centrifuged at $3000 \mathrm{~g}$ and $4{ }^{\circ} \mathrm{C}$ for $10 \mathrm{~min}$. The serum was stored at $-70{ }^{\circ} \mathrm{C}$ for later biochemical analysis.

Measurement of Serum Cholesterol and Triglyceride (TG) Levels Levels of TC, TG, and HDL-C in serum were determined by enzymatic colormetric methods using commercial kits [Shinyang Chemical Co., Ltd. (Korea)]. The concentration of LDL-cholesterol (LDL-C) and the antherogenic index (A.I.) were calculated by the following equations according to the methods of Kim et al. ${ }^{21)}$ and Choi et al. ${ }^{22)}$

$$
\begin{aligned}
& \text { LDL }-\mathrm{C}=\mathrm{TC}-\mathrm{HDL}-\mathrm{C}-\frac{1}{5} \mathrm{TG} \\
& \text { A.I. }=(\mathrm{TC}-\mathrm{HDL}-\mathrm{C}) / \mathrm{HDL}-\mathrm{C}
\end{aligned}
$$

Statistics All results are presented as mean \pm S.E.M. The data were evaluated by one-way ANOVA using the SPSS program, and the differences between the means were assessed using Duncan's test. Statistical significance was considered at $p<0.05, p<0.01$, and $p<0.001$.

\section{RESULTS}

Serum Lipid Profiles in Poloxamer 407-Induced Hyperlipidemic Rats Table 1 shows the effects of the $\mathrm{MeOH}$ extract and 4 fractions of $S$. flavescens on the serum lipid levels of the hyperlipidemic rats induced by poloxamer 407. Elevated serum TC, TG, and LDL-C levels were lowered by the $\mathrm{MeOH}$ extract of $S$. flavescens. Serum HDL-C was also reduced in the poloxamer 407-induced hyperlipidemic control rats, however, oral administration of the EtOAc fraction significantly increased HDL-C levels. Above all, the cholesterol-lowering effect of the EtOAc fraction from $S$. flavescens was very strong, and of the tested fractions, the EtOAc fraction was highly antiatherogenic with A.I. values of less than 1.92 .

The effects of kurarinol and kuraridinol, which were isolated from the EtOAc fraction of $S$. flavescens, on the serum lipid levels of the poloxamer 407-induced hyperlipidemic rats are shown in Table 2. The serum TC, TG, and LDL-C levels of the poloxamer 407-induced hyperlipidemic control rats markedly increased, but the administration of both kurarinol and kuraridinol significantly reduced serum $\mathrm{TC}, \mathrm{TG}$, and LDL-C levels. The HDL-C levels of the poloxamer 407induced hyperlipidemic control rats also decreased, however,

Table 1. Effect of $\mathrm{MeOH}$ Extract and Its $\mathrm{CH}_{2} \mathrm{Cl}_{2}$, EtOAc, $n-\mathrm{BuOH}$ and $\mathrm{H}_{2} \mathrm{O}$ Soluble Fractions of Sophora flavescens on Serum Lipid and Lipoprotein Lev-

\begin{tabular}{|c|c|c|c|c|c|c|}
\hline Groups & $\begin{array}{c}\text { Dose } \\
\text { (mg/kg bw) }\end{array}$ & $\begin{array}{c}\mathrm{TC} \\
(\mathrm{mg} / \mathrm{dl})\end{array}$ & $\begin{array}{c}\mathrm{TG} \\
(\mathrm{mg} / \mathrm{dl})\end{array}$ & $\begin{array}{l}\text { HDL-C } \\
(\mathrm{mg} / \mathrm{dl})\end{array}$ & $\begin{array}{l}\text { LDL-C } \\
(\mathrm{mg} / \mathrm{dl})\end{array}$ & A.I. \\
\hline Control & - & $327.50 \pm 8.41$ & $282.42 \pm 10.46$ & $22.11 \pm 0.92$ & $241.30 \pm 4.09$ & $13.59 \pm 1.08$ \\
\hline \multirow[t]{2}{*}{$\mathrm{MeOH}$ extract } & 250 & $\begin{array}{c}238.75 \pm 3.66^{\# \#} \\
\quad(72.90)\end{array}$ & $\begin{array}{c}236.81 \pm 8.65^{\#} \\
(83.85)\end{array}$ & $\begin{array}{c}46.83 \pm 0.47^{\# \#} \\
(211.80)\end{array}$ & $\begin{array}{c}144.82 \pm 7.13^{\# \#} \\
(60.02)\end{array}$ & $\begin{array}{l}4.10 \pm 0.04^{\# \#} \\
(30.17)\end{array}$ \\
\hline & 500 & $\begin{array}{c}226.69 \pm 2.74^{\# \#} \\
(69.22)\end{array}$ & $\begin{array}{c}222.25 \pm 9.76^{\#} \\
(78.69)\end{array}$ & $\begin{array}{c}50.63 \pm 0.73^{\# \#} \\
(228.99)\end{array}$ & $\begin{array}{c}130.61 \pm 5.09^{\# \#} \\
(54.13)\end{array}$ & $\begin{array}{c}3.38 \pm 0.03^{\mathrm{\# \#}} \\
(24.87)\end{array}$ \\
\hline $\mathrm{CH}_{2} \mathrm{Cl}_{2}$ fraction & 100 & $\begin{array}{c}239.06 \pm 9.28^{\#} \\
(72.99)\end{array}$ & $\begin{array}{c}256.48 \pm 9.86 \\
(90.81)\end{array}$ & $\begin{array}{c}40.91 \pm 0.19^{\# \#} \\
(185.03)\end{array}$ & $\begin{array}{c}157.58 \pm 9.71^{\# \#} \\
(65.30)\end{array}$ & $\begin{array}{c}5.07 \pm 0.32^{\# \#} \\
(37.31)\end{array}$ \\
\hline \multirow[t]{2}{*}{ EtOAc fraction } & 50 & $\begin{array}{c}202.71 \pm 4.89^{\# \#} \\
\quad(61.90)\end{array}$ & $\begin{array}{c}220.33 \pm 4.02^{\#} \\
\quad(78.02)\end{array}$ & $\begin{array}{c}51.39 \pm 0.63^{\# \#} \\
(232.43)\end{array}$ & $\begin{array}{c}111.17 \pm 3.50^{\# \#} \\
(46.07)\end{array}$ & $\begin{array}{l}3.03 \pm 0.07^{\# \#} \\
(22.30)\end{array}$ \\
\hline & 100 & $\begin{array}{c}175.42 \pm 8.26^{\# \#} \\
(53.56)\end{array}$ & $\begin{array}{c}192.53 \pm 5.68^{\# \#} \\
(68.17)\end{array}$ & $\begin{array}{c}60.04 \pm 0.68^{\# \#} \\
(271.55)\end{array}$ & $\begin{array}{l}77.04 \pm 10.71^{\# \#} \\
(31.93)\end{array}$ & $\begin{array}{l}1.92 \pm 0.17^{\# \#} \\
(14.13)\end{array}$ \\
\hline$n$-BuOH fraction & 100 & $\begin{array}{l}239.58 \pm 11.32^{\# \#} \\
\quad(73.15)\end{array}$ & $\begin{array}{c}255.16 \pm 9.82 \\
(90.34)\end{array}$ & $\begin{array}{c}34.26 \pm 1.38^{\# \#} \\
(154.95)\end{array}$ & $\begin{array}{c}155.85 \pm 16.40^{\# \#} \\
(64.59)\end{array}$ & $\begin{array}{l}6.23 \pm 0.45^{\# \#} \\
(45.84)\end{array}$ \\
\hline $\mathrm{H}_{2} \mathrm{O}$ fraction & 100 & $\begin{array}{c}266.88 \pm 8.23^{\#} \\
(81.49)\end{array}$ & $\begin{array}{c}279.34 \pm 8.58 \\
(98.91)\end{array}$ & $\begin{array}{c}34.13 \pm 0.97^{\# \#} \\
(154.36)\end{array}$ & $\begin{array}{l}177.78 \pm 10.27^{\# \#} \\
\quad(73.68)\end{array}$ & $\begin{array}{l}7.09 \pm 0.46^{\# \#} \\
(52.17)\end{array}$ \\
\hline
\end{tabular}
els in Poloxamer 407-Induced Hyperlipidemic Rats ${ }^{a}$

a) $\mathrm{TC}=$ total cholesterol; $\mathrm{TG}=$ triglyceride; HDL-C=high-density lipoprotein cholesterol; LDL-C=low-density lipoprotein cholesterol; A.I.=atherogenic index. Figures in parentheses are percentages of the control value. Values are mean \pm S.E.M. $(n=6)$. $\# p<0.05, \# p<0.001 v s$. control value.

Table 2. Effect of Kurarinol and Kuraridinol Isolated from Sophora flavescens on Serum Lipid and Lipoprotein Level in Poloxamer 407-Induced Hyper-

\begin{tabular}{|c|c|c|c|c|c|c|}
\hline Groups & $\begin{array}{c}\text { Dose } \\
(\mathrm{mg} / \mathrm{kg} \mathrm{bw})\end{array}$ & $\begin{array}{c}\mathrm{TC} \\
(\mathrm{mg} / \mathrm{dl})\end{array}$ & $\begin{array}{c}\mathrm{TG} \\
(\mathrm{mg} / \mathrm{dl})\end{array}$ & $\begin{array}{l}\text { HDL-C } \\
(\mathrm{mg} / \mathrm{dl})\end{array}$ & $\begin{array}{l}\text { LDL-C } \\
(\mathrm{mg} / \mathrm{dl})\end{array}$ & A.I. \\
\hline Control & - & $268.04 \pm 12.02$ & $300.94 \pm 5.86$ & $28.95 \pm 1.99$ & $179.43 \pm 12.43$ & $8.86 \pm 1.16$ \\
\hline \multirow[t]{2}{*}{ Kurarinol } & 10 & $\begin{array}{c}240.56 \pm 5.05 \\
(89.75)\end{array}$ & $\begin{array}{c}287.63 \pm 4.63 \\
\quad(95.58)\end{array}$ & $\begin{array}{c}33.92 \pm 1.75 \\
(117.17)\end{array}$ & $\begin{array}{l}149.11 \pm 5.73 \\
\quad(83.10)\end{array}$ & $\begin{array}{l}6.22 \pm 0.50 \\
(70.20)\end{array}$ \\
\hline & 20 & $\begin{array}{c}225.13 \pm 5.46^{\#} \\
(83.99)\end{array}$ & $\begin{array}{c}271.50 \pm 6.02^{\#} \\
(90.22)\end{array}$ & $\begin{array}{l}37.66 \pm 1.08^{\#} \\
(130.09)\end{array}$ & $\begin{array}{c}133.17 \pm 5.52^{\#} \\
(74.22)\end{array}$ & $\begin{array}{l}5.01 \pm 0.27^{\#} \\
(56.55)\end{array}$ \\
\hline \multirow[t]{2}{*}{ Kuraridinol } & 10 & $\begin{array}{c}194.30 \pm 6.79^{\# \#} \\
(72.49)\end{array}$ & $\begin{array}{c}243.38 \pm 2.82^{\# \#} \\
(80.87)\end{array}$ & $\begin{array}{c}40.38 \pm 1.32^{\# \#} \\
(139.48)\end{array}$ & $\begin{array}{c}105.24 \pm 2.45^{\# \#} \\
(58.65)\end{array}$ & $\begin{array}{l}3.84 \pm 0.18^{\#} \\
(43.34)\end{array}$ \\
\hline & 20 & $\begin{array}{c}149.58 \pm 4.46^{\# \#} \\
(55.81)\end{array}$ & $\begin{array}{c}228.15 \pm 3.33^{\# \#} \\
(75.81)\end{array}$ & $\begin{array}{c}47.44 \pm 0.88^{\# \#} \\
(163.87)\end{array}$ & $\begin{array}{c}56.93 \pm 5.94^{\# \#} \\
(31.73)\end{array}$ & $\begin{array}{c}2.16 \pm 0.13^{\# \#} \\
(24.37)\end{array}$ \\
\hline
\end{tabular}
lipidemic Rats $^{a)}$

a) $\mathrm{TC}=$ total cholesterol; $\mathrm{TG}=$ triglyceride; HDL-C $=$ high-density lipoprotein cholesterol; LDL-C=low-density lipoprotein cholesterol; A.I. $=$ atherogenic index. Figures in parentheses are percentages of the control value. Values are mean \pm S.E.M. $(n=6)$. $\# p<0.05, \# p<0.001 v s$. control value. 
Table 3. Effect of Kurarinol and Kuraridinol Isolated from Sophora flavescens on Serum Lipid and Lipoprotein Levels in Rats Fed on a High-Cholesterol $\operatorname{Diet}^{a)}$

\begin{tabular}{|c|c|c|c|c|c|c|}
\hline Groups & $\begin{array}{c}\text { Dose } \\
(\mathrm{mg} / \mathrm{kg} \mathrm{bw})\end{array}$ & $\begin{array}{c}\mathrm{TC} \\
(\mathrm{mg} / \mathrm{dl})\end{array}$ & $\begin{array}{c}\mathrm{TG} \\
(\mathrm{mg} / \mathrm{dl})\end{array}$ & $\begin{array}{l}\text { HDL-C } \\
(\mathrm{mg} / \mathrm{dl})\end{array}$ & $\begin{array}{l}\text { LDL-C } \\
(\mathrm{mg} / \mathrm{dl})\end{array}$ & A.I. \\
\hline Control & - & $302.21 \pm 8.49$ & $289.46 \pm 5.11$ & $13.91 \pm 0.94$ & $230.91 \pm 9.10$ & $20.45 \pm 1.52$ \\
\hline Kurarinol & 20 & $\begin{array}{c}264.43 \pm 6.10^{\#} \\
(87.50)\end{array}$ & $\begin{array}{c}253.95 \pm 4.94^{\# \#} \\
(87.73)\end{array}$ & $\begin{array}{c}18.87 \pm 0.96^{\#} \\
(135.66)\end{array}$ & $\begin{array}{c}194.73 \pm 6.80^{\#} \\
(84.43)\end{array}$ & $\begin{array}{l}13.40 \pm 0.75^{\#} \\
(65.55)\end{array}$ \\
\hline Kuraridinol & 20 & $\begin{array}{c}248.45 \pm 7.42^{\#} \\
(82.21)\end{array}$ & $\begin{array}{c}239.07 \pm 3.50^{\# \#} \\
(82.59)\end{array}$ & $\begin{array}{c}21.28 \pm 0.41^{\# \#} \\
(152.98)\end{array}$ & $\begin{array}{c}183.83 \pm 8.70^{\#} \\
(79.96)\end{array}$ & $\begin{array}{c}11.12 \pm 0.64^{\# \#} \\
(54.37)\end{array}$ \\
\hline
\end{tabular}

a) $\mathrm{TC}=$ total cholesterol; $\mathrm{TG}=$ triglyceride; HDL-C=high-density lipoprotein cholesterol; LDL-C=low-density lipoprotein cholesterol; A.I.=atherogenic index. Figures in parentheses are percentages of the control value. Values are mean \pm S.E.M. $(n=7)$. $\# p<0.05$, \# $p<0.001 v s$. control value.

HDL-C was significantly increased from 28.95 to $37.66 \mathrm{mg} / \mathrm{dl}$ and to $47.44 \mathrm{mg} / \mathrm{dl}$ by administering kurarinol and kuraridinol, respectively, at a dose of $20 \mathrm{mg}(p<0.05$, $0.001)$. The A.I. was significantly reduced in a dose-dependent manner by the administration of kurarinol and kuraridinol. In particular, kuraridinol exhibited more effective lipid lowering activities on the hyperlipidemic rats than kurarinol.

Serum Lipid Profiles in Cholesterol-Fed Rats The serum lipid profiles and A.I. values of the rats fed the highcholesterol diet combined with oral doses of kurarinol and kuraridinol at $20 \mathrm{mg} \mathrm{mg} / \mathrm{kg}$ of body $\mathrm{wt} / \mathrm{d}$ for $3 \mathrm{~d}$ are summarized in Table 3. Serum TC, TG, and LDL-C levels in the cholesterol-fed control rats markedly increased, whereas oral administration of both kurarinol and kuraridinol led to significant decreases in lipid levels compared to the cholesterol-fed control rats. In addition, the reduced HDL-C levels of the cholesterol-fed control rats were significantly increased in the rats given kurarinol and kuraridinol compared to the control rats. The A.I. was also significantly reduced by administering kurarinol and kuraridinol.

\section{DISCUSSION}

It is well known that one of the major risk factors of atherosclerosis is hyperlipidemia. ${ }^{23)}$ Hyperlipidemia and high cholesterol diets increase serum TC and LDL-C levels, resulting in an increased risk for the development of atherosclerosis. Thus, regulating the serum cholesterol level is important in atherosclerosis prevention, as it has been shown that atherosclerosis could be suppressed by controlling the level of serum cholesterol. Recently, there has been focus on the cholesterol-lowering effects of dietary plants, and various plants are shown to be helpful in lowering plasma cholesterol levels. $^{24-27)}$ In the present study, we investigated the effects of $S$. flavescens and its constituents on the serum lipid profiles of hypercholesterolemic rats and rats with poloxamer $407-$ induced hyperlipidemia.

Poloxamer 407, which is a nonionic surfactant and is nontoxic to cellular membranes, was used successfully to induce hyperlipidemia in previous studies. ${ }^{28,29}$ Poloxamer 407 has been utilized in the hyperlipidemic model due to its convenience, reproducibility, and lack of undesirable underlying pathological conditions. ${ }^{28)}$ In this study, we employed poloxamer 407-induced hyperlipidemic rats as our hyperlipidemic animal model, and within this model, investigated the hypolipidemic effects of the $\mathrm{MeOH}$ extract and 4 fractions of $S$. flavescens.
An increased cholesterol concentration in the plasma may cause coronary atherosclerosis to develop. ${ }^{3)}$ In addition, serum TG is also considered an important risk factor for atherosclerosis. ${ }^{30,31)}$ Elevated levels of plasma TG and LDL-C, accompanied by reduced HDL-C levels, are often associated with an increased risk of coronary heart disease. ${ }^{32)}$ In particular, many studies have found LDL-C to be the most dangerous among the serum lipids, and the oxidation of LDL leads to its increased penetration of arterial walls. ${ }^{33,34)}$ When there is excess LDL in the blood, it is deposited in the blood vessel walls and becomes a major component of atherosclerotic plaque lesions. Moreover, in animal experiments, the LDL of hypercholesterolemic rabbits was more susceptible to oxidative modification than that of normolipidemic rabbits. ${ }^{35)}$ This oxidative modification of LDL is causally involved in the initiation and promotion of atherosclerosis. ${ }^{36)}$ Thus, an increased cholesterol level can be a significant predictor of the development of coronary artery disease, and serum LDL-C levels should be used as the basis for initiating and monitoring treatment of patients with elevated blood cholesterol. ${ }^{37,38)}$ According to these studies, lowering serum TC and LDL-C levels is important for reducing the risk of atherosclerosis.

In the present study, the hyperlipidemic rats induced by poloxamer 407 showed high serum levels of TC and TG, but oral administration of the $\mathrm{MeOH}$ extract and the 4 fractions of $S$. flavescens reduced high TC levels (Table 1). In addition, serum LDL-C levels were significantly reduced by both the $\mathrm{MeOH}$ extract and 4 fractions of $S$. flavescens. Therefore, the results imply that $S$. flavescens extract has beneficial effects on serum lipid profiles by reducing lipid levels (Table $1)$.

HDL carries cholesterol and cholesterol esters from the peripheral tissues and cells to the liver, where cholesterol is metabolized into bile acids. ${ }^{39)}$ This pathway plays a very important role in reducing cholesterol levels in the blood and peripheral tissues, and in inhibiting atherosclerotic plaque formation in the aorta. ${ }^{40)}$ Our results showed that the $\mathrm{MeOH}$ extract and 4 fractions of $S$. flavescens increased serum HDL-C concentrations when compared with the poloxamer 407-induced hyperlipidemic control rats. These results suggest that $S$. flavescens is an effective lipid lowering agent and may protect against cardiovascular diseases that result from hyperlipidemia.

The A.I. is believed to be an important risk factor for atherosclerosis, and was significantly lowered in the poloxamer 407-induced hyperlipidemic rats administered the $\mathrm{MeOH}$ extract or 4 fractions of $S$. flavescens. This decrease in the A.I. 
is yet another positive change resulting from the $S$. flavescens treatments. In particular, the EtOAc fraction showed a stronger lipid-lowering effect than the other fractions, as well as a high antiatherogenic potential, with atherogenic index (A.I.) values of less than 1.92 (Table 1). Therefore, we isolated the active compounds from the EtOAc fraction and identified them as kurarinol and kuraridinol. We then investigated the hyperlipidemic and hypercholesterolemic effects of kurarinol and kuraridinol using the poloxamer 407-induced hyperlipidemic and cholesterol-fed rats. Both kurarinol and kuraridinol reduced TC, TG, and LDL-C levels and increased serum HDL-C levels in the poloxamer 407-induced hyperlipidemic rats (Table 2). These findings showed that kurarinol and kuraridinol may be helpful in ameliorating plasma lipid profiles.

Ross $^{41)}$ reported that experimental animals that consumed high dietary levels of cholesterol developed elevated LDL-C levels and atherosclerosis, and suggested the pathological process could be reversed by reducing serum LDL-C levels. Here, our findings also demonstrated that rats fed a cholesterol-rich diet had higher concentrations of $\mathrm{TC}$, TG, and LDL-C, and reduced levels of HDL-C. The high concentrations of TC, TG, and LDL-C induced by the diet were significantly reduced by the oral administration of kurarinol and kuraridinol (Table 3). Kurarinol and kuraridinol may also inhibit atherogenesis in rats fed a cholesterol diet by improving A.I. values. These results indicate that both kurarinol and kuraridinol may act as hypocholesterolemic agents for preventing hypercholesterolemic atherosclerosis by lowering serum lipid levels.

Flavonoids are polyphenolic compounds found in small quantities in numerous plant foods, including fruits, vegetables, tea, wine, nuts, seeds, herbs, and spices. ${ }^{42,43)}$ Flavonoids are antioxidants and may therefore reduce the oxidation of LDL cholesterol, which is thought to be involved in the development of atherosclerotic disease. ${ }^{44-46)}$ Epidemiologic data suggest that dietary flavonoids may have beneficial cardiovascular effects in human populations. Several prospective studies have reported statistically significant inverse associations between total flavonoid intake, and the intake of specific classes of flavonoids, and cardiovascular disease incidence and mortality. ${ }^{43,47-50)}$ Kurarinol is reported to be a prenylated flavanone and an effective inhibitor of alpha-glucosidase and beta-amylase, as well as diacylglycerol acyltransferase activity. ${ }^{51-53)}$ Kuraridinol is a chalcone compound belonging to the prenylated flavonoids and was reported to be a major compound in the extract of $S$. flavescens. ${ }^{54)}$ In the present study, both kurarinol and kuraridinol showed significant hyperlipidemic and hypercholesterolemic effects by lowering serum cholesterol levels, and kuraridinol exhibited stronger protective activities against hyperlipidemia than kurarinol. In support of this, Santos et al. reported that chalcone compounds had significant anti-lipidemic activity. ${ }^{55)}$

In summary, the present study demonstrated that $S$. flavescens and its components, kurarinol and kuraridinol, had hypolipidemic effects in poloxamer 407-induced hyperlipidemic rats, where the compounds significantly lowered serum TC, TG, and LDL-C concentrations, elevated HDL-C levels, and decreased serum A.I. values. In addition, kurarinol and kuraridinol showed the same effects in cholesterol- fed rats. These results suggest that kurarinol and kuraridinol from $S$. flavescens may be beneficial in preventing atherosclerotic cardiovascular diseases.

Acknowledgements This study was supported by a grant from the Food and Drug Administration, Republic of Korea (2005).

\section{REFERENCES}

1) Lovegrove J. A., Jackson K. G., “Coronary Heart Disease,” ed. by Gibson G. R., Williams C. M., Functional Foods, Woodhead, Cambridge, 2000, pp. 97-139.

2) Castelli W. B., Garrison R. J., Wilson P. W. F., Abbott R. D., Kalousdian S., Kannel W. B., JAMA, 256, 2835-2838 (1986).

3) Kannel W. B., Castelli W. P., Gordon T., Ann. Intern. Med., 90, 85-91 (1979).

4) Gordon D. J., Rifkind B. M., N. Engl. J. Med., 321, 1311-1316 (1989).

5) Anderson K. M., Wilson P. W., Odell P. M., Kannel W. B., Circulation, 83, 356-362 (1991).

6) Berliner J. A., Navab M., Fogelma A., Frank J. S., Demer L. L., Edwards P. A., Watson A. D., Lusis A. J., Circulaiton, 91, 2488-2496 (1995).

7) Levine G. N., Keaney J. F., Jr., Vita J. A., N. Engl. J. Med., 332, $512-$ 521 (1995).

8) Ghule B. V., Ghante M. H., Saoji A. N., Yeole P. G., Indian J. Exp. Biol., 44, 905-909 (2006).

9) Lemhadri A., Hajji L., Michel J. B., Eddouks M., J. Ethnopharmacol., 106, 321-326 (2006).

10) Yagi A., Fukunaga M., Okuzako N., Mifuchi I., Kawamoto F., Shoyakugaku Zasshi, 43, 343-347 (1989).

11) Tang W., Eisenbrand G., "Chinese Drugs of Plant Origin,” Springer, Heidelberg, 1992, pp. 931-943.

12) Bae K. H., Kim Y. K., Min B. S., Arch. Pharm. Res., 20, 342-345 (1997).

13) Ryu S. Y., Lee H. S., Kim Y. K., Kim S. H., Arch. Pharm. Res., 20, 491-495 (1997).

14) Lee H. S., Ko H. R., Ryu S. Y., Oh W. K., Kim B. Y., Ahn S. C., Mheen T. I., Ahn J. S., Planta Med., 63, 266-268 (1997).

15) Kang T. H., Jeong S. J., Ko W. G., Kim N. Y., Lee B. H., Inagaki M., Miyamoto T., Higuchi T., Kim Y. C., J. Nat. Prod., 63, 680-681 (2000).

16) Ha T. J., Yang M. S., Jang D. S., Choi S. U., Park K. H., Bull. Kor Chem. Soc., 22, 97-99 (2001).

17) De Naeyer A., Vanden Berghe W., Pocock V., Milligan S., Haegeman G., De Keukeleire D., J. Nat. Prod., 67, 1829-1832 (2004).

18) Piao X. L., Piao X. S., Kim S. W., Park J. H., Kim H. Y., Cai S. Q., Biol. Pharm. Bull., 29, 1911-1915 (2006).

19) Jung H. J., Kang S. S., Woo J. J., Choi J. S., Arch. Pharm. Res., 28, 1333-1336 (2005).

20) Schmolka I. R., "Polymers for Controlled Drug Delivery," ed. by Tarch P. J., CSC Press, Boca Raton, pp. 189-215, 1991.

21) Kim Y. H., Seong N. S., Lee Y. J., Kor. J. Herbol., 20, $91-102$ (2005).

22) Choi J. S., Yokozawa T., Oura H., J. Nat. Prod., 1, 218 -224 (1991).

23) Genest J., McNamara J. R., Ordow M. J. M., Siberman S. R., Anderson K. M., Wilson P. W., Salem D. M., Schaefer E. J., J. Am. Coll. Cardiol., 19, 792-802 (1992).

24) Bhandari U., Sharma J. N., Zafar R., J. Ethnopharmacol., 61, 167171 (1998).

25) Ghasi S., Nwobodo E., Ofili J. O., J. Ethnopharmacol., 69, 21-25 (2000).

26) Nimenibo-Uadia R., Trop. J. Pharm. Res., 2, 183-189 (2003).

27) Choudhary M. I., Naheed S., Jalil S., Alam J. M., Rahman A., J. Ethnopharmacol., 98, 217-220 (2005).

28) Wout Z. G., Pec E. A., Maggiore J. A., Williams R. H., Palicharla P., Johnston T. P., J. Parenter. Sci. Technol., 46, 192-200 (1992).

29) Eliot L. A., Foster R. T., Jamali F., Pharm. Res., 16, 309-313 (1999).

30) Jones J. D., Chambliss M. L., Arch. Fam. Med., 9, 189-190 (2000).

31) Hopkins P. N., Wu L. L., Hunt S. C., Brinton E. A., J. Am. Coll. Cardiol., 45, 1003-1012 (2005).

32) Smith S. C., Jr., Jackson R., Pearson T. A., Fuster V., Yusuf S., Faerge- 
man O., Wood D. A., Alderman M., Horgan J., Home P., Hunn M., Grundy S. M., Circulation, 109, 3112-3121 (2004).

33) Steinberg D., Parthasarathy S., Carew T., Khoo J., Witztum J., N. Engl. J. Med., 320, 915-924 (1989).

34) Aviram M., Atherosclerosis, 98, $1 \longrightarrow 9$ (1993).

35) Nenseter M. S., Gudmundsen O., Malterud K. E., Berg T., Drevon C. A., Biochim. Biophys. Acta, 1213, 207-214 (1994).

36) Steinberg D., N. Engl. J. Med., 328, 1487-1489 (1993).

37) The Expert Panel, JAMA, 269, 3015-3023 (1993).

38) Schaefer E. J., Lichtenstein A. H., Lamon-Fava S., McNamara J. R., Ordovas J. M., Am. J. Clin. Nutr., 61, 726S-740S (1995).

39) Stein O., Stein Y., Atherosclerosis, 144, 285-301 (1999).

40) Young C. E., Karas R. H., Kuvin J. T., Cardiol. Rev., 12, 107-119 (2004).

41) Ross R., Nature (London), 362, 801-809 (1993).

42) Graf B. A., Milbury P. E., Blumberg J. B., J. Med. Food, 8, 281-290 (2005).

43) Hertog M. G., Kromhout D., Aravanis C., Blackburn H., Buzina R., Fidanza F., Giampaoli S., Jansen A., Menotti A., Nedeljkovic S., Arch. Intern. Med., 155, 381-386 (1995).

44) Vinson J. A., Su X., Zubik L., Bose P., J. Agric. Food Chem., 49, 5315-5321 (2001).

45) Kris-Etherton P. M., Keen C. L., Curr. Opin. Lipidol., 13, 41-49
(2002).

46) O’Byrne D. J., Devaraj S., Grundy S. M., Jialal I., Am. J. Clin. Nutr., 76, 1367-1374 (2002).

47) Knekt P., Jarvinen R., Reunanen A., Maatela J., Brit. Med. J., 312, 478-481 (1996).

48) Knekt P., Kumpulainen J., Järvinen R., Rissanen H., Heliövaara M., Reunanen A., Hakulinen T., Aromaa A., Am. J. Clin. Nutr., 76, 560568 (2002)

49) Arts I. C., Jacobs D. R., Jr., Harnack L. J., Gross M., Folsom A. R., Epidemiology, 12, 668-675 (2001).

50) Geleijnse J. M., Launer L. J., Van der Kuip D. A., Hofman A., Witteman J. C., Am. J. Clin. Nutr., 75, 880-886 (2002).

51) Woo E. R., Kwak J. H., Kim H. J., Park H., J. Nat Prod., 61, 15521554 (1998).

52) Chung M. Y., Rho M. C., Ko J. S., Ryu S. Y., Jeune K. H., Kim K., Lee H. S., Kim Y. K., Planta Med., 70, 258-260 (2004).

53) Kim J. H., Ryu Y. B., Kang N. S., Lee B. W., Heo J. S., Jeong I. Y., Park K. H., Biol. Pharm. Bull., 29, 302-305 (2006).

54) Zhang L., Xu L., Xiao S. S., Liao Q. F., Li Q., Liang J., Chen X. H., Bi K. S., J. Pharm. Biomed. Anal., 44, 1019-1028 (2007).

55) Santos L., Curi Pedrosa R., Correa R., Cechinel Filho V., Nunes R. J., Yunes R. A., Arch. Pharm. (Weinheim), 339, 541-546 (2006). 